\title{
By way of introduction: the rule of law as a strategic priority for EU external action-conceptualization and implementation of $\mathbf{E} \mathbf{U}$ law and policies
}

\author{
Kolja Raube $^{1} \cdot$ Matthieu Burnay $^{1} \cdot$ Jan Wouters ${ }^{1}$
}

Published online: 29 September 2015

(C) Springer-Verlag Berlin Heidelberg 2015

\section{Rule of law as part of European traditions and policies}

The rule of law is a principle of governance which signifies that decisions by the government should be taken according to the law and that the government itself should be subject to the law. Therefore, historically, the rule of law has acted as the ultimate barrier against the arbitrary power of the ruler and served to oppose the 'unbridled, unaccountable royal power of the Monarchs' (Bingham 2011, p. 12). While the concept finds its origins in Ancient Greece, where it contributed to the 'self-definition of the political community of the City' (Harris in May 2012, p. 240), Europe has since acted as the centre of the construction of the rule of law. This may be seen particularly through the development of the traditions of the French état de droit, the German Rechtsstaatlichkeit and the English rule of law. It is therefore unsurprising that the European Union (EU) was later qualified as a 'Community based on the rule of law'.

It is in these words that the European Court of Justice made its first ever reference to the rule of law back in 1986. In addition, the rule of law has been part of the EU Treaties ever since the 1992 Maastricht Treaty on European Union. The preamble of the Maastricht Treaty reaffirmed the EU's 'attachment to the principles of liberty, democracy and respect for human rights and fundamental freedoms and of the rule of law'. The rule of law has, in this respect, progressively been recognized as one of the EU's constitutional pillars (Pech 2010). With the entry into force of the Treaty of Lisbon on 1 December 2009, one can surmise that the rule of law has reached the status of a foundational value of the EU. As Article 2 of the Treaty on European Union (TEU) reads, '[t]he Union is founded on the values of respect for human dignity, freedom, democracy, equality, the rule of law and respect for human rights, including the rights

${ }^{1}$ C 294/83, Les Verts vs the European Parliament, Judgment of the Court, 23 April 1986, paragraph 23

Matthieu Burnay

Matthieu.burnay@ggs.kuleuven.be

1 Leuven Centre for Global Governance Studies, Leuven, Belgium 
of persons belonging to minorities [...].' Not only does the principle matter in the EU's internal affairs, it is also applied externally: Article 21 TEU places the rule of law and the promotion of the rule of law firmly at the centre of the EU's external action (Magen 2009; Pech 2012). Article 21(1) TEU reads as follows: 'The Union's action on the international scene be guided by the principles which have inspired its own creation, development and enlargement, and which it seeks to advance in the wider world: democracy, the rule of law, the universality and indivisibility of human rights and fundamental freedoms, respect for human dignity, the principles of equality and solidarity, and respect for the principles of the United Nations Charter and international law'.

Nevertheless, it is only recently that the EU seems to have re-discovered the virtues of the rule of law as a constitutional pillar of the EU and as a strategic priority in the EU's external actions. Domestically, it is arguable that three rule of law crises served to remind the EU that its 'legal and democratic fabric' (Barroso 2012) could still be threatened. These crises concerned the independence of the judiciary in Hungary, the non-respect of constitutional court judgments in Romania and the rights of Roma people in France. It is in this spirit that the European Commission released a Communication in the spring of 2014 on 'A New EU Framework to Strengthen the Rule of Law', which proposes instruments to address threats to the rule of law within the EU (2014).

Overshadowed by the related principles of democracy and human rights and their external promotion, the rule of law has returned to the forefront as a strategic priority in the EU's external relations rather discretely. This renascent interest for the rule of law in the EU's external action is occurring at a time where reflection on the rule of law in the United Nations context has been reaffirmed at the occasion of the 2012 High Level Meeting on the Rule of Law at the National and International Levels. Indeed, in September 2012, the United Nations General Assembly (UNGA) adopted by consensus a Declaration which emphasized that the rule of law implies that 'all persons, institutions and entities, public and private, including the State itself, are accountable to just, fair and equitable laws and are entitled without any discrimination to equal protection of the law' (United Nations General Assembly 2012).

The EU's external promotion of norms and values has become widely observed over the last years. In this context, the EU has been described as a 'normative power' or 'cosmopolitan' power (Forsberg 2011; Manners 2002; Sjursen 2006). Advocating norms and values which it is based upon itself, the debate has focused mainly on the promotion of human rights and democracy, especially on how far such promotion should go. It is only recently that the academic literature has started to assess systematically the external promotion of the rule of law by the EU. The rule of law had, in fact, long been analysed simply as an annex to the EU's external promotion of human rights and democracy (see for example Magen et al. 2013). Against this background, we propose that, in light of recent research by Nicolaidis and Kleinfeld (2012), the rule of law and its external promotion by the EU need to be analysed in their own right. Situating rule of law promotion at the heart of EU external relations research-rather than in the context of human rights and democracy promotion-will enable us to understand how, and which, rule of law conceptions are promoted by the EU internationally. More particularly, this special issue will help us to define whether the EU advocates in favour of a thin or a thick version of the rule of law (Craig 2005). A thin version of the rule of law refers to a minimal understanding of the rule of law and 
includes the fundamental conditions to have a legal system. A thick version of the rule of law goes beyond the formalistic and procedural perspective of the rule of law and also looks to the ideal of justice promoted by the law. This special issue will also enable us to identify the discrepancies between the internal and external aspects of the EU's rule of law promotion in a time where coherence functions as the premier avenue to secure the 'effectiveness, legitimacy and credibility' of its external action (Marangoni and Raube 2014, p. 486). Finally, this special issue will also enable us to analyse how the EU relates to the debate on the international level as currently defined in the UN context.

\section{Conceptualizing and implementing EU rule of law promotion}

In light of the different rule of law traditions in EU Member States and the EU's commitment to the rule of law as a constitutional pillar of its internal and external actions and the global rule of law developments, the present special issue adopts two research perspectives. First, it considers how the EU approaches the rule of law as a strategic priority in a coherent manner; second, it investigates how the EU translates the rule of law concept into actual policies of rule of law promotion and implementation on the ground.

As regards the former, it needs to be assessed whether one can actually observe a coherent EU approach towards the rule of law. Is the EU able to overcome differences between the Member States in their understanding and application of the rule of law and translate it into a coherent approach in its external relations (see Magen, this special issue)? Or, do we see a 'disconnect' between the EU's internal and external policies and instruments (see Pech, this special issue)? The question that arises is whether the EU is able to develop a legal pluralist approach to the EU's rule of law promotion 'which focuses on the user perspective of citizens and which recognizes the contested notion of the rule of law across cultural borders' (see Hertogh, this special issue).

As regards the translation of rule of law promotion into policies and implementation on the ground, it needs to be verified whether the rule of law as a strategic priority of EU external action is addressed autonomously by the EU, or whether it actually forms a 'trias' with the promotion of human rights and democracy. Does the rule of law inform policies autonomously in order to eradicate certain problems such as corruption and insecurity on the ground (see Schmitz, this special issue; Cravo, this special issue) and guide bilateral rule of law dialogues with external partners (see Burnay, Hivonnet and Raube, this special issue)? Or, does it go hand in hand with democracy promotion on the ground (see Muftuler-Bac, this special issue)?

Both at the level of the conceptualization and implementation of the EU's rule of law policies, it appears to be necessary to understand the extent to which the EU's perspective on the rule of law contradicts with other perspectives on the rule of law. In fact, the elusive nature of the rule of law becomes quickly obvious when one notes the absence of a common definition at the global level. As observed by S. Chesterman, 'the content of the term 'rule of law' (...) remains contested across both time and geography' (2008, p. 340). The question therefore arises whether the EU rule of law would simply be 'dead on arrival' or whether the confrontation with different rule of law traditions would also inform the reflection on the rule of law within the EU (Burnay, Hivonnet and Raube, this special issue). 


\section{Assessing the EU's rule of law promotion}

Focusing on the EU's conceptualization and implementation on the ground, the contributions in this special issue identify a number of challenges and opportunities with regard to the EU's external rule of law promotion.

The first article by Pech assesses what is in the legal dimension of the rule of law in the EU's external action. It, first and foremost, addresses the 'definitional problem' that the EU faces with regard to the rule of law. According to Pech, 'the lack of any formal definition in the EU Treaties means that the rule of law, as a foreign policy objective, does not impose precise obligations on EU institutions but rather operates as a 'soft' ideal' (Ibid.). Against this background, Pech proceeds to suggest 'that consistency and effectiveness of EU's action have been further undermined by the absence of a comprehensive and conceptually sound framework'. For Pech, a number of practical solutions, evidenced in other international organizations, may be of value, including an 'EU Rule of Law Guidance Note' and 'Rule of Law Index'.

Complementing Pech's, Magen's assessment reveals that the EU currently struggles with what he calls a 'two diversity and one consistency dilemma'. In Magen's words, 'The first diversity dilemma pertains to the great divergence in the current uses and understandings of the concept of the Rule of Law', whereas 'the second emanates from empirical reality'. While the EU is far from being able to agree internally on what the 'rule of law' concept entails, it is at the same time faced by 'a diverse, arguably diversifying, set of political regimes' outside of its borders. Moreover, the EU faces one particular additional dilemma: 'Grappling with diversity in a clear-eyed manner while, at the same time, maintaining policy coherence, represents the third major challenge [...].' (Ibid.). Magen proposes that the EU should invest in the making of a rule of law strategy which views 'the Rule of Law as a core dimension (arguably the core dimension) of political development in human societies' (Ibid.).

Addressing the question of how the EU can approach the rule of law externally, Marc Hertogh proposes that, based on empirical findings in Thailand, the EU should opt for a bottom-up approach in its rule of law action, advocating a legal pluralist perspective on rule of law promotion.

Turning to the empirical evidence of the EU's rule of law promotion on the ground, the case studies in this special issue focus on Turkey, Indonesia, China, Georgia and Guinea-Bissau. All case studies assess the EU's ability and instruments to promote the rule of law vis-à-vis external partners. Meltem Muftuler-Bac offers a critical account of the EU's interrelated objectives of enlargement, accession criteria, democracy and the rule of law. Regarding Turkey, 'an interesting case study to assess the impact of the European Union on upholding rule of law in a country that has not yet become a member', Muftuler-Bac shows how 'EU conditionality stimulated the political transformation in Turkey and led to the surfacing of the suppressed conflict between secularists and Islamists, unexpectedly highlighting illiberal forces in the country'. Indeed, the EU's ultimate goal of the rule of law and democratization has actually backfired, driving Turkey into a situation which can be considered worse compared to the status quo ante and leaving the EU with a highly ineffective rule of law promotion.

However, the case of Indonesia appears to be very different. In his case study on Indonesia and the external effect of the EU Timber Regulation, Schmitz demonstrates how 'being normative does not imply the neglect of hard power politics' as shown by 
the compliance of the partner country. He concludes that 'sticks and carrots do help in achieving compliance from other international actors', especially as 'there was much to gain (and lose) for Indonesian decision-makers in economic terms' (Ibid.).

In the case of China, however, the EU's ability to achieve concrete results in rule of law promotion is less evident. Burnay, Hivonnet and Raube show the difficult diplomatic task to agree between the EU and China on the scope and substance of a common rule of law dialogue as a specific soft-diplomatic tool in the context of the EU-China Strategic Partnership. Often seen by the Chinese as an interference in their domestic affairs, their contribution points to the difficulties of the EU to reach out to China and establish a rule of law dialogue between the two partners. However, it also points to the light at the end of the tunnel: a potential 'legal affairs dialogue' between the two partners.

Finally, Cravo analyses the rule of law as a tool to tackle security threats in the aftermath of crisis management, especially in the area of Security Sector Reform (SSR). Cravo finds that in the context of peace and state building, the EU approaches third countries as the 'intervener' on the basis of a 'Liberal Peace' concept, through which the 'rule of law and SSR have been equated with the transplantation of liberal legal frameworks into the state institutional apparatus'. However, this approach of the EU has, according to Cravo, 'undermined the aims of curbing instability and fostering development'.

Overall, this special issue sheds considerable light on the external rule of law promotion of the EU. The contributions illustrate that the rule of law is a rich field of study in view of a newly emerging strategic priority of the EU. While the contributions show the intrinsic link with democracy and human rights promotion (see Muftuler$\mathrm{Bac}$ ), it appears that the rule of law is progressively emancipating itself as a principle of EU external action in its own right (see Pech; Magen; Hertogh; Schmitz; Burnay, Hivonnet and Raube; Cravo). At the same time, findings of this special issue also point to the conceptual challenges of diversity, consistency and strategy (Pech; Magen), as well as of the external acceptance and perception of the EU's external promotion of the rule of law (Hertogh). Last but not least, the contributions point to the varying degrees of influence that the EU asserts vis-à-vis external partners (Burnay, Hivonnet and Raube; Schmitz) and the effects that EU rule of law policies can have in third countries (Muftuler-Bac and Cravo).

\section{References}

Barroso, JMD (2012) State of the Union address, plenary session of the European Parliament, available at http://ec.europa.eu/soteu2012/files/soeu_web.pdf

Bingham T (2011) The rule of law, Penguin Books

Chesterman S (2008) The international rule of law. Am J Comp Law 56(2):331-361

Communication from the Commission to the European Parliament and Council, 'A new EU Framework to strengthen the Rule of Law', 11 March 2014, available at http://ec.europa.eu/justice/effective-justice/files/ com_2014_158_en.pdf

Craig P (2005) Formal and substantive conceptions of the rule of law: an analytical framework in Richard Bellamy (ed.), The rule of law and the separation of powers, Ashgate 95-115

European Union (2014) A new EU framework to strengthen the rule of law. Brussels

Forsberg T (2011) Normative power Europe, once again: a conceptual analysis of an ideal type. J Common Mark Stud 49(6):1183-1204 
Magen A (2009) The rule of law and its promotion abroad: three problems of scope. Stanf J Int Law 45:51115

Magen A, Risse T and McFaull M (2013) Promoting democracy and the rule of law-American and European strategies. Palgrave Macmillan

Manners I (2002) Normative power Europe: a contradiction in terms? J Common Mark Stud 40(2):235-258

Marangoni A-C and Raube K (2014) Virtue or vice? The coherence of the EU's external policies, Journal of European Integration, 36

May C (2012) The rule of law: Athenian antecedents to contemporary debates, The Hague Journal on the Rule of Law, 4

Nicolaidis K and Kleinfeld R (2012) Rethinking Europe's 'Rule of Law' and enlargement agenda: the fundamental dilemma, The Jean Monnet Working Paper Series, Jean Monnet Working Paper 12/12

Pech L (2010) A union founded on the rule of law: meaning and reality of the rule of law as a constitutional principle of EU law. Eur Constit Law Rev 6(2010):359-396

Pech L (2012) Rule of law as a guiding principle of the European Union's external action, in Cleer Working Papers 2012/3

Sjursen H (2006) The EU as a 'normative' power: how can this be? J Eur Public Policy 13(2):235-251

United Nations General Assembly (2012) Declaration of the high-level meeting of the General Assembly high level meeting on the Rule of Law at the National and International Levels, A/67/L.1, adopted by consensus 